\title{
Cervical Symmetrical Lipomatosis
}

National Cancer Institute

\section{Source}

National Cancer Institute. Cervical Symmetrical Lipomatosis. NCI Thesaurus. Code C4392.

A neoplastic process characterized by a symmetric poorly circumscribed overg rowth of adipose tissue in the neck. It predominantly affects middle age men of Mediterranean origin. 